Терапевтична стоматологія

УдК 616.314-07-08-057:625

DOI 10.11603/2311-9624.2017.1.7763

(C). С. Кіцак, Т. Б. Мандзюк

вдНЗУ «Буковинський державний медичний університет», м. Чернівці

\title{
Стан стоматологічної захворюваності у провідників пасажирських вагонів Чернівецького вузла Львівської залізниці
}

Резюме. Дослідження, спрямовані на виявлення закономірностей формування здоров’я провідників пасажирських вагонів під впливом виробничих чинників з метою наукового обгрунтування малозатратних та ефективних заходів оздоровлення, мають велике значення, оскільки тривалий вплив шкідливих чинників на організм погіршує стан здоров'я та призводить до виникнення різноманітних захворювань, що негативно впливає на виконання робітниками службових обов’язків.

Мета дослідження - вивчити стан твердих тканин зубів, оцінити інтенсивність і особливості клінічних проявів як каріозного процесу, так і некаріозних уражень твердих тканин зубів у провідників пасажирських вагонів станції Чернівці.

Матеріали і методи. Для вирішення поставлених завдань обстежили 52 особи, з них 30 провідників пасажирських вагонів станції Чернівці (основна група) і 22 особи, які не зазнають впливу шкідливих чинників (група порівняння). Усіх пацієнтів поділили на чотири вікові групи й обстежили їх згідно 3 рекомендаціями ВООЗ. Оцінку стану зубів проводили за індексом КПВ.

Результати досліджень та їх обговорення. Поширеність карієсу в провідників пасажирських вагонів становить 100 \% у всіх вікових групах, кількість уражених карієсом зубів залежно від стажу роботи та віку коливається від 20,0 до 25,97. Тільки половина зубів, уражених карієсом, лікується. Залежно від віку, від 12 до 53 \% зубів видаляють.

Висновки. Рекомендуємо відновити програми профілактики стоматологічних захворювань, які б включали в себе стоматологічну освіту працівників, навчання правилам раціонального харчування, а татож гігієнічного догляду за порожниною рота, вторинну профілактику (планову санацію ротової порожнини), диспансерне спостереження.

Ключові слова: ротова порожнина; карієс; пломба.

(C). С. Кицак, Т. Б. Мандзюк

ВГузУ «Буковинский государственный медицинский университет», г. Черновцы

\section{Состояние стоматологической заболеваемости в проводников пассажирских вагонов Черновицкого узла Львовской железной дороги}

Резюме. Исследования, направленные на выявление закономерностей формирования здоровья проводников пассажирских вагонов под влиянием производственных факторов с целью научного обоснования малозатратных и эффективных мер оздоровления, имеют большое значение, поскольку длительное воздействие вредных факторов на организм ухудшает состояние здоровья и приводит к возникновению различных заболеваний, негативно влияет на выполнение рабочими служебных обязанностей.

Цель исследования - изучить состояние твердых тканей зубов, оценить интенсивность и особенности клинических проявлений как кариозного процесса, так и некариозных поражений твердых тканей зубов у проводников пассажирских вагонов по станции Черновцы.

Материалы и методы. Для решения поставленных задач нами проведено обследование 52 человек, из них 30 проводников пассажирских вагонов по станции Черновцы (основная группа) и 22 работников, не подвергающихся воздействию вредных факторов (группа сравнения). Все пациенты разделены на четыре возрастные группы и обследованы согласно рекомендациям ВОЗ. Оценка состояния зубов проводилась по индексу КПУ.

Результаты исследований и их обсуждение. Распространенность кариеса у проводников пассажирских вагонов составляет 100 \% во всех возрастных группах, количество пораженных кариесом зубов в зависимости от стажа работы и возраста колеблется от 20,0 до 25,97. Только 
половина зубов, пораженных кариесом, лечится. В зависимости от возраста, от 12 до 53 \% зубов удаляется.

Выводы. Рекомендуем восстановить программы профилактики стоматологических заболеваний, которые бы включали в себя стоматологическое образование работников, обучение правилам рационального питания, а также гигиенического ухода за полостью рта, вторичную профилактику (плановую санацию ротовой полости), диспансерное наблюдение.

Ключевые слова: ротовая полость; кариес; пломба.

\section{CT. S. Kitsak, T. B. Mandziuk}

Bukovynian State Medical University

\section{State of dental morbidity rate among passenger car attendants of Chernivtsi Railroad Centre of Lviv Railroad}

Summary. The study aimed at identifying health leaders peculiarities forming carriages under the influence of factors of production for the purpose of scientific justification of low-cost and effective recovery measures are important because prolonged exposure to harmful factors on the health worsens and leads to various diseases, which adversely affects the workers to perform their duties.

The aim of the study - to examine the state of dental hard tissues, to assess the intensity and peculiarities of clinical manifestations of both carious process and non-carious affects of dental hard tissues among the passenger car attendants of Chernivtsi station.

Materials and Methods. To solve the tasks we examined 52 people, including 30 passenger car attendants of Chernivtsi station (treatment group) and 22 employees not exposed to harmful factors (experimental group). All patients were divided into four age groups and examined according to recommendations of World Health Organization on dental examination. Teeth assessment was conducted according to CFE (caries, filled, extracted) index.

Results and Discussion. The degree of caries expansion among the passenger car attendants is $100 \%$ in all age groups, the number affected teeth with caries depending on the length of service and age ranges from 20.0 to 25.97. Only half of teeth affected by caries is treated. Depending on the age from $12 \%$ to $53 \%$ of teeth are extracted.

Conclusions. We recommend to restore the programs of dental diseases prevention that would include dental education of the employees, learning the rules of sensible nutrition, learning the rules of the mouth cavity hygienic care, secondary prevention (planned oral cavity sanation), dispensary observation.

Key words: oral cavity; caries; filling.

Вступ. На Чернівецькому вузлі Львівської залізниці працює 3661 залізничник, з них провідники складають найбільшу частку - 484 (13,2 \%). Під час виконання своїх професійних обов'язків провідники потягів пасажирського залізничного сполучення постійно знаходяться під впливом низки шкідливих чинників: різкі зміни температурного режиму, шум та вібрація, запиленість, підвищениий рівень мікробної забрудненості повітря вагонів, порушення режиму сну та відпочинку, психофізіологічні й нервово-емоційні навантаження. Ріст стоматологічної захворюваності у людей, професійна діяльність яких пов'язана 3 хронічним впливом на їхні органи шкідливих чинників виробництва, пов’язують із ростом хронічних супутніх соматичних захворювань, зміною антиоксидантно-прооксидантної системи тканин порожнини рота, мікробної рівноваги, токсичною гіпоксією. Протягом трудової діяльності на працівників впливають різні шкідливі чинники виробничого середовища, тому умови праці на виробництві значною мірою визначаються наявністю виробничих шкідливостей. Під виробничими шкідливостями розуміють умови виробничого середовища, які за нераціональної організації праці впливають на стан здоров'я працівників та їхню працездатність.

Залежно від характеру походження, виробничі шкідливості поділяються на: шкідливості, пов'язані з трудовим процесом, що зу- 
мовлені нераціональною організацією праці (надмірним напруженням нервової системи, напругою органів зору, слуху, великою інтенсивністю праці тощо); шкідливості, пов’язані з виробничим процесом, що створюються за рахунок технічних недоліків виробничого устаткування (промислового пилу, шуму, вібрації, шкідливих хімічних речовин, випромінювання). В Україні щорічно в середньому реєструється 7,5-8 тис. професійних захворювань, що само собою свідчить про труднощі й неоднозначність оцінок у використанні цих показників для висновків та прийняття організаційних і управлінських рішень.

Дослідження, спрямовані на виявлення закономірностей формування здоров'я провідників пасажирських вагонів під впливом виробничих чинників із метою наукового обгрунтування малозатратних та ефективних заходів оздоровлення, мають велике значення, оскільки тривалий вплив шкідливих чинників на організм погіршує стан здоров'я та призводить до виникнення різноманітних захворювань, що негативно впливає на виконання робітниками службових обов'язків.

Мета дослідження - вивчити стан твердих тканин зубів, оцінити інтенсивність і особливості клінічних проявів як каріозного процесу, так і некаріозних уражень твердих тканин зубів у провідників пасажирських вагонів станції Чернівці.

Матеріали і методи. Для вирішення поставлених завдань ми провели обстеження 52 осіб, 3 них 30 провідників пасажирських вагонів станції Чернівці (основна група) i 22 осіб, які не зазнають впливу шкідливих чинників (група порівняння). Усіх пацієнтів поділили на чотири вікові групи й обстежені згідно з рекомендаціями ВОО3. Оцінку стану зубів проводили за індексом КПВ. Дослідження стоматологічної захворюваності у провідників пасажирських вагонів ми проводили в чотирьох вікових групах: перша група 19-24 роки, друга група - 25-34 роки, третя група - 35-44 роки і четверта група - 45 років і старше. У кожній віковій категорії сформовано основну групу з працівників, які безпосередньо задіяні у виробничому процесі, й контрольна група працівників, не задіяних у виробничому циклі. Всього було обстежено 52 особи.

При обстеженні твердих тканин зубів та якості їх лікування ми, окрім сумарного значення індексу КПВ, проводили розгорнутий аналіз його складових, а саме, в показнику К-карієс враховували кількість зубів із неускладненим і ускладненим карієсом. Зуби 3 ускладненим карієсом, у свою чергу, поділяли на ті, що підлягають лікуванню, і ті, які підлягають видаленню.

У складову індексу П (пломби) включили кількість пломб, що потребують заміни, до яких відносили: зруйновані пломби і реставрації; пломби та реставрації на апроксимальних поверхнях із неякісним контактним пунктом і нависаючими краями.

Коронки виділили в окрему групу, із загальної кількості яких так само виділяли неякісні, в основному, це відсутність контактного пункту і наявність нависаючих країв.

До складової «В» відносили відсутні на час огляду зуби.

Результати досліджень та їх обговорення. Ми вивчили стан зубів у провідників пасажирських вагонів залежно від віку і стажу роботи. Поширеність карієсу в провідників складає 100 \% у всіх вікових групах. В основній групі у віці 19-24 роки інтенсивність ураження зубів становить 20 зубів, сягаючи у віці 45 і старше років майже 26 зубів на одну обстежену особу. Темп приросту уражених зубів не великий, але стабільний, близько двох уражених зубів на кожну вікову групу. В контрольній групі значення індексу КПВ майже на 20 \% менше у всіх вікових групах і приріст уражених зубів на половину менше, ніж у контрольній групі.

Кількість зубів, уражених карієсом (К), у структурі КПВ в основній групі зростає від 2,5 (12,50 \%) у віці 19-24 р. до 6,42 (26,52 \%) у третій віковій групі (35-44 р.) і в четвертій віковій групі (45 і старше) знижується до 4,77 $(18,37 \%)$. Це зниження відбувається за рахунок збільшення кількості видалених зубів. В основній групі складова КПВ - «К» стабільна у межах чотирьох уражених зубів у всіх вікових групах, крім працівників молодого віку, де вона дорівнює 2,4 ураженого зуба.

Кількість запломбованих зубів в основній групі зменшується удвічі, від 15,0 у першій віковій групі до 7,52 у четвертій. У групі порівняння складова КПВ - «П» стабільна у всіх вікових групах і знаходиться в межах 12-13 пломб на одного обстеженого.

Показник інтенсивності руйнування зубів зумовлений кількістю видалених зубів. В основній групі питома вага видалених зубів «В» в індексі КПВ у першій віковій групі становить $12,30 \%$ і зростає на 40,37 \% у четвертій 
віковій групі (52,67 \%), тобто більше, як у чотири рази. В контрольній групі кількість видалених зубів у 2,5 раза менше.

Кількість видалених зубів в основній групі 3 віком значно перевищує кількість лікованих зубів. На один видалений зуб у молодому віці припадає шість вилікованих, а у IV віковій групі на один видалений зуб припадає лише 0,5 лікованих. У контрольній групі у всіх вікових групах (за винятком першої групи, де на один видалений зуб 13 лікованих) на один видалений припадає від трьох до чотирьох лікованих.

Висновки. В основній і контрольній групах при огляді діагностується ускладнений карі$є c$, що вказує на недостатній рівень санації порожнини рота. Проте в основній групі цей показник перевершує аналогічний у контрольній у першій, другій, третій вікових групах в 3,90; 5,18; 2,63 раза $(\mathrm{p}<0,05)$ відповідно, а у четвертій групі кількість зубів з ускладненим карієсом на 0,28 раза в контрольній групі перевищує показник основної (p>0,05). Ускладнений карієс у контрольній групі розвивається рівномірно до 34 років ( $>0,05)$, а в третій віковій (до 44 р.) групі різко зростає у три раза порівняно з першою віковою групою. Надалі, зі збільшенням віку залишається на одному рівні (p>0,05). В основній групі динаміка розвитку ускладненого карієсу виглядає інакше - спочатку діагностують збільшення кількості зубів з ускладненим карієсом майже у два рази у віці до 34 років $(\mathrm{p}<0,05)$, далі, від 34 до 44 років кількість уражених зубів залишається приблизно на одному рівні (p>0,05), після 44 років діагностується різке зниження уражених зубів у 2,5 раза $(\mathrm{p}<0,05)$. Для оцінки тяжкості ураження зубів, ускладнених карієсом, ми провели аналіз стану зубів, що підлягають лікуванню і видаленню.

Як видно з даних обстеження, у першій віковій групі кількість зубів з ускладненим карієсом, що підлягають лікуванню, в основній і контрольних групах однакова та близько в 1,75 раза перевершує кількість зубів, які підлягають видаленню. У другій віковій групі кількість зубів, що підлягають лікуванню і видаленню в основній групі, майже однакова, а в контрольній зуби, які підлягають лікуванню, у два рази перевищують кількість тих, що підлягають видаленню. У четвертій віковій групі відсоток зубів, що підлягають лікуванню, в основній і контрольній групах на 10-15 \% менше, ніж зубів, які підлягають видаленню.
Це вказує на приблизно однакове недостатнє звернення обстежених за стоматологічною допомогою, а також недостатню якість лікування.

Незначне зростання кількості запломбованих зубів в основній групі спостерігається від першої до третьої вікової групи (від 0,66 до $1,66)$, надалі у четвертій групі знижується до 1,6. У контрольній групі таке зростання відмічене лише в другій групі до 3,33; у третій і четвертій вікових групах діагностують зниження запломбованих зубів майже у два рази.

Крім того, якість пломб досить низька, тому що вже у віці 19-24 роки в контрольній групі 17,37 \% пломб, які потребують заміни, а в основній ця цифра досягає 57,64 \%. У віці 25-34 роки відбувається подальше збільшення неякісних пломб у основній групі на 17,33 \%, а в контрольній - на 18,27 \%. У старшій віковій групі підвищується кількість неякісних пломб в обох групах до 50 \%, і знижується загальна їх кількість.

Обсяг стоматологічної допомоги в усіх обстежених дуже низький, практично $50 \%$ первинних каріозних уражень не лікується. Якість пломб - незадовільна. Поєднання цих двох показників свідчить про повну відсутність планового стоматологічного лікування. Лікування здійснюють лише на 30 \% необхідного обсягу за зверненням. На нашу думку, таке положення виникло за відсутності диспансеризації працівниць підприємств із шкідливими виробничими чинниками.

Аналіз кількості видалених зубів, з одного боку, характеризує якість та обсяг стоматологічної допомоги обстежених. 3 іншого боку - швидкий перебіг патологічних процесів у твердих тканинах зуба і пародонті, що призводить до їх повної втрати.

3 віком, у основній групі проходить значне зростання видалених зубів і динаміка цього збільшення значно стрімкіша порівняно 3 контрольною групою.

Таким чином, приріст видалених зубів в основній групі майже у два рази перевищує такий у контрольній групі (p<0,05), а питома вага видалених зубів у складі КПВ в основній групі у півтора раза вище, ніж у контрольній групі.

Поширеність карієсу в провідників пасажирських вагонів становить 100 \% у всіх вікових групах, кількість уражених карієсом зубів, залежно від стажу роботи та віку, коливається від 20,0 до 25,97. Тільки половина зубів, уражених карієсом, лікується. Залежно від віку, від 12 до 53 \% зубів видаляють. 
Відсутність програм профілактики при високій ураженості карієсом зубів та його ускладненнями, висока поширеність захворювань парадонта призводить до збільшення потреби у терапевтичному, хірургічному й ортопедичному лікуванні. При цьому лікування відбувається практично тільки за зверненням.

\section{Список літератури}

1. Данилевский Н. Ф. Заболевания пародонта / Н. Ф. Данилевский, А. В. Борисенко. - К. : Здоров’я, 2000. -462 с.

2. Вагнер В. Д. Пособие по стоматологии / В. Д. Вагнер. - М. : Мед. книга ; Н. Новгород : Изд-во НГМА, 2003. -264 c.

3. Мащенко И. С. Заболевания пародонта / И. С. Мащенко. - Днепро : Коло, 2003. - 272 с.

4. Терапевтическая стоматология : учебник для студентов по специальности «Стоматология» / под ред. Е. В. Боровского. - 3-е изд. - М. : МИА, 2006. - 798 с.

5. Захворювання пародонту / М. Ф. Данилевський, А. В. Борисенко, А. М. Політун [та ін.]. - К. : Медицина, 2008. - 614 c.

\section{REFERENCES}

1. Danilevskiy, N.F. (2000). Zabolevaniya parodonta [Periodontal disease]. Kyiv: Zdorovia [in Russian].

2. Vagner, V.D. (2003). Posobie po stomatologii [The manual on stomatology]. Novgorod: Izd-vo NGMA [in Russian].

3. Mashchenko, I.S. (2003). Zabolevaniya parodonta [Periodontal disease]. Dnepro: Kolo [in Russian].

4. Borovskiy, E.V. (Ed.). (2006). Terapevticheskaya stomatologiya [Therapeutic dentistry]. Moscow: MIA [in Russian].

5. Danylevskyi, M.F., Borysenko, A.V., \& Politun, A.M. (2008). Zakhvoriuvannia parodontu [Periodontal disease]. Kyiv: Medytsyna [in Ukrainian].

6. Kamalov, R.Kh. (Ed.). (2001). Diahnostyka, likuvannia $i$ profilaktyka zakhvoriuvan parodonta: metod.
Ми рекомендуємо відновити програми профілактики стоматологічних захворювань, які б включали в себе стоматологічну освіту працівників, навчання правилам раціонального харчування, гігієнічного догляду за порожниною рота, вторинну профілактику (планову санацію ротової порожнини), диспансерне спостереження.

6. Камалов Р. Х. Діагностика, лікування і профілактика захворювань пародонта : метод. рекомендації / уклад. Р. Х. Камалов. - К. : Знання, 2001. - 42 с.

7. Николаев А. И. Практическая терапевтическая стоматология / А. И. Николаев, Л. М. Цепов. - СПб., 2001. - 390 c.

8. Хвороби тканин пародонта. Етіологія. Патогенез. Діагностика. Лікування / О. Р. Ріпецька, І. С. Денега, В. С. Гриновець, М. В. Гисик. - Л. : Ліга-Прес, 2004. $170 \mathrm{c.}$

9. Мащенко I. С. Запальні та дистрофічні захворювання пародонта : навч. посіб. з терапевтичної стоматології / І. С. Мащенко - Л. : АРТ-ПРЕС, 2003. - 244 с.

rekomendatsii [Diagnosis, treatment and prevention of periodontal diseases: method. recommendations]. Kyiv: Znannia [in Ukrainian].

7. Nikolaev, A.I. (2001). Prakticheskaya terapevticheskaya stomatologiya [Practical therapeutic stomatology]. Saint-Petersburg [in Russian].

8. Ripetska, O.R., Deneha, I.S., Hrynovets, V.S. \& Hysyk, M.V. (2004). Khvoroby tkanyn parodonta. Etiolohiia. Patohenez. Diahnostyka. Likuvannia [Diseases of periodontal tissues. Etiology. Pathogenesis. Diagnosis. Treatment]. Lviv: Liha-Pres [in Ukrainian].

9. Mashchenko, I.S. (2003). Zapalni ta dystrofichni zakhvoriuvannia parodonta [Inflammatory and degenerative periodontal disease]. Lviv: ART-PRES [in Ukrainian]. 